\title{
Emissions of Ammonia, Carbon Dioxide and Particulate Matter from Cage-Free Layer Houses in California
}

Xingjun. Lin ${ }^{1}$, Ruihong Zhang ${ }^{1}$, Shumei Jiang ${ }^{1}$, Hamed El-Mashad ${ }^{1,2}$ and Hongwei Xin ${ }^{3}$

${ }^{1}$ Biological and Agricultural Engineering Department, University of California-Davis

${ }^{2}$ Agricultural Engineering Department, Faculty of Agriculture, Mansoura University, Daqahlia, Egypt

${ }^{3}$ Agricultural and Biosystems Engineering Department, Iowa State University

Corresponding author: Ruihong Zhang, One Shields Avenue, Davis, CA 95616, USA, Department of Biological and Agricultural Engineering, University of California, phone: 530-754-9530, fax: 530-7522640; e-mail: rhzhang@ucdavis.edu.

\section{Abstract}

Cage-free housing systems have attracted considerable attention in the United States recently as they provide more space and other resources (such as litter area, perches, and nest boxes) for hens and are considered to be more favorable from the standpoint of hen welfare. This study was carried out to quantify emissions of aerial ammonia $\left(\mathrm{NH}_{3}\right)$, carbon dioxide $\left(\mathrm{CO}_{2}\right)$ and particulate matter $\left(\mathrm{PM}_{10}\right.$ and $\left.\mathrm{PM}_{2.5}\right)$ from cage-free layer houses in California and compare the values with those for other types of layer houses. Two commercial cage-free houses with 38,000 hens each were monitored from March 1, 2012 to April 1, 2013. Results show that $\mathrm{NH}_{3}$ and $\mathrm{CO}_{2}$ concentrations in the houses were affected by ventilation rate, which was largely influenced by ambient air temperature. The $\mathrm{PM}_{10}$ and $\mathrm{PM}_{2.5}$ concentrations in the houses depended on the activity of birds, ventilation rate and relative humidity of the ambient air. The average emission rates of $\mathrm{NH}_{3}, \mathrm{CO}_{2}, \mathrm{PM}_{10}$ and $\mathrm{PM}_{2.5}$ were $0.29,89.9,0.163$ and $0.020 \mathrm{~g} \mathrm{~d}^{-1}$ hen ${ }^{-1}$, respectively. The $\mathrm{NH}_{3}$ emission rate determined in this study was similar to those reported in the literature for manure-belt layer houses but higher than those of aviary houses. The $\mathrm{PM}_{10}$ and $\mathrm{PM}_{2.5}$ emission rates were higher than those reported for high-rise layer houses.

KEYWORDS: Ventilation rate, Laying-hen, Egg production, Bird activity, Continuous monitoring. 


\section{Introduction}

In 2014, California had 13.6 million laying hens, and was ranked $6^{\text {th }}$ nationally in egg production (USDA, 2014). Egg production industry has undergone considerable scrutiny from public and regulatory agencies due to their environmental impacts resulting from emissions of air pollutants. Ammonia $\left(\mathrm{NH}_{3}\right)$, carbon dioxide $\left(\mathrm{CO}_{2}\right)$, and particulate matter $\left(\mathrm{PM}_{10}\right.$ and $\left.\mathrm{PM}_{2.5}\right)$ are the main pollutants of concerns from layer production facilities. High $\mathrm{NH}_{3}$ concentrations in hen houses could adversely affect the health and welfare of hens and workers (Xin et al., 2011; Zhao et al., 2013). The $\mathrm{NH}_{3}$ concentration at bird level should be less than $10 \mathrm{ppm}$ and must not exceed $25 \mathrm{ppm}$, and $\mathrm{CO}_{2}$ concentration should be less than 3000 ppm and must not exceed 5000 ppm (HFAC Laying Hen Standards, 2014). The emitted pollutants can be dispersed in the atmosphere and deposited downwind from layer farms. The $\mathrm{NH}_{3}$ in the atmosphere contributes to acid rain, eutrophication of surface water and acidification of soil. Moreover, $\mathrm{NH}_{3}$ is a precursor of fine particulate matter (Gay and Knowlton, 2013). $\mathrm{PM}_{10}$ and $\mathrm{PM}_{2.5}$ are among the criteria pollutants regulated by the Clean Air Act in the United States. Their health hazards are lung and heart diseases.

Environmental footprint of egg production depends on several factors such as housing systems, management, and weather conditions. Housing system designs affect the environments inside the housing and therefore air emissions and comfort and health of hens (Xin et al., 2011). Housing systems for hens include conventional cage, aviary, cage-free and free-range. Until recently, approximately $95 \%$ of the laying hen houses in the United States use conventional cage style (Zhao et al., 2015a). However, there has been a growing opposition to the conventional cage housing systems due to the small size of cages and lack of resources for birds to exercise their natural behaviors. Consequently, some countries (mainly in the European Union) and certain states in the US have enacted regulations that require larger spaces be provided to the hens or transit to enriched colony or cage-free housing systems. For example, California passed a law that requires provision of enough space for laying hens to freely lie down, stand up, turn around, and extend their wings (Health and Safety Code, 2013). Large living space is also believed to help 
prevent the Salmonella Enteritidis infection in hens (CDFA, 2013). Enriched colony, aviary and other types of cage-free houses are recommended to replace the existing conventional cage houses.

Measurement and monitoring of the emissions on layer farms have been conducted by researchers for different housing systems. Determination of the emissions of different pollutants from different poultry housing systems enables comparison of the environmental impact of different housing systems, developing regulatory emission thresholds, and exploring effective emission mitigation methodologies. Shepherd et al. (2015) measured concentrations and emissions of $\mathrm{NH}_{3}, \mathrm{CO}_{2}, \mathrm{~N}_{2} \mathrm{O}, \mathrm{CH}_{4}$ and $\mathrm{PM}_{10}$ of an aviary house in the Midwest USA for a period of 28 months. Zhao el al. (2013) monitored the emission rate of $\mathrm{NH}_{3}$ in four aviary houses for two days every two weeks over one year in Iowa. Dekker et al. (2011) measured the emission rates of $\mathrm{NH}_{3}, \mathrm{~N}_{2} \mathrm{O}$ and $\mathrm{CH}_{4}$ from three aviary houses at selected 8-day periods over one year. With the increasing interests of adopting cage-free housing systems, long-term continuous monitoring of air emissions from cage-free houses is needed in order to determine diurnal and seasonal variations of emission rates caused by the changes in climatic conditions and farm management practices over time. The objectives of this study were to: (1) continually quantify the emissions rates of $\mathrm{NH}_{3}, \mathrm{CO}_{2}$, and particulate matter $\left(\mathrm{PM}_{10}, \mathrm{PM}_{2.5}\right)$ in two cage-free layer houses in California for 13 months; and (2) compare the emission magnitudes of these pollutants to those for other layer housing systems.

\section{Methodologies}

\subsection{Description of Monitoring Sites}

The emissions of $\mathrm{NH}_{3}, \mathrm{CO}_{2}$, and particulate matter $\left(\mathrm{PM}_{10}, \mathrm{PM}_{2.5}\right)$ were monitored in two houses on a layer farm located in San Joaquin Valley, California. The two houses, denoted as H1 and H2, were oriented north to south and built in 2009 and 2008, respectively. Each house held 38,000 brown Lohman hens (Fig.1D). There was no molting during one laying cycle of 56 weeks. The two houses were $15.3 \mathrm{~m}$ apart (Fig. 1A). Each house had the dimensions of $135 \mathrm{~m}$ long $\times 17 \mathrm{~m}$ wide $\times 4 \mathrm{~m}$ high at eave, and the ridge height of $6.9 \mathrm{~m}$. It had two floors, with the first and second floor height being $1.8 \mathrm{~m}$ and $2.1 \mathrm{~m}$, respectively. The cage-free houses were built following the standard of the American Humane Association for cage-free houses (AHA, 2013) using the main parameters listed in S1. Each floor had four nesting rows 
with feed, water supply, nests, and perches. A cross section of the building is shown in Fig.1C. Manure belts were used to remove manure collected under the nesting rows thrice per week. The hen living area in each floor was separated by two wire meshes into three pens along the length. Each pen held approximately 6,000 hens. There was an 8-m wide open floor area in the middle of the house. At the beginning of a flock, the floor was covered with 5-cm rice hulls. The mixture of the rice hulls and manure were cleaned out at the end of the flock. With both wire mesh and litter floor areas included, the average area allocated to each hen was $1168 \mathrm{~cm}^{2}\left(181 \mathrm{in}^{2}\right)$ which was greater than the area $\left(568 \mathrm{~cm}^{2}\left(88 \mathrm{in}^{2}\right)\right)$ required for each hen to freely flap wings in 1000 hens per pen (Mench, 2013).

The monitoring site was setup in December 2011, and data were collected from 3/1/2012 to 4/1/2013. The periods (from 7/23/2012 to 8/15/2012 in $\mathrm{H} 1$ and from 2/23/2013 to 3/12/2013 in H2) with zero inventory were non-production between after removal of the spent hens and preparation of the houses for receiving the new flock. During the 56-week production period, body weight of the hens averaged $1.72 \pm 0.18 \mathrm{~kg}$ and the daily feed use averaged $122 \pm 13 \mathrm{~g} \mathrm{hen}^{-1} \mathrm{~d}^{-1}$. The rate of egg production (or hen-day egg production) was $80 \%$ with an average egg weight of $62 \mathrm{~g}$. Cumulative mortality rate was $22 \%$ of the initial inventory as of 56 weeks of age. Lin et al. (2015) reported mortality rates of $11.6 \%$ in aviary, $4.3 \%$ in conventional cage and $4.8 \%$ in enriched colony houses located in the Midwest. The high mortality rate in the current study might be due to the higher piling probability resulting from the higher number of hens per pen $(6000$ hen/pen) than that (852-1702 hen/pen) reported by Lin et al. (2015). 

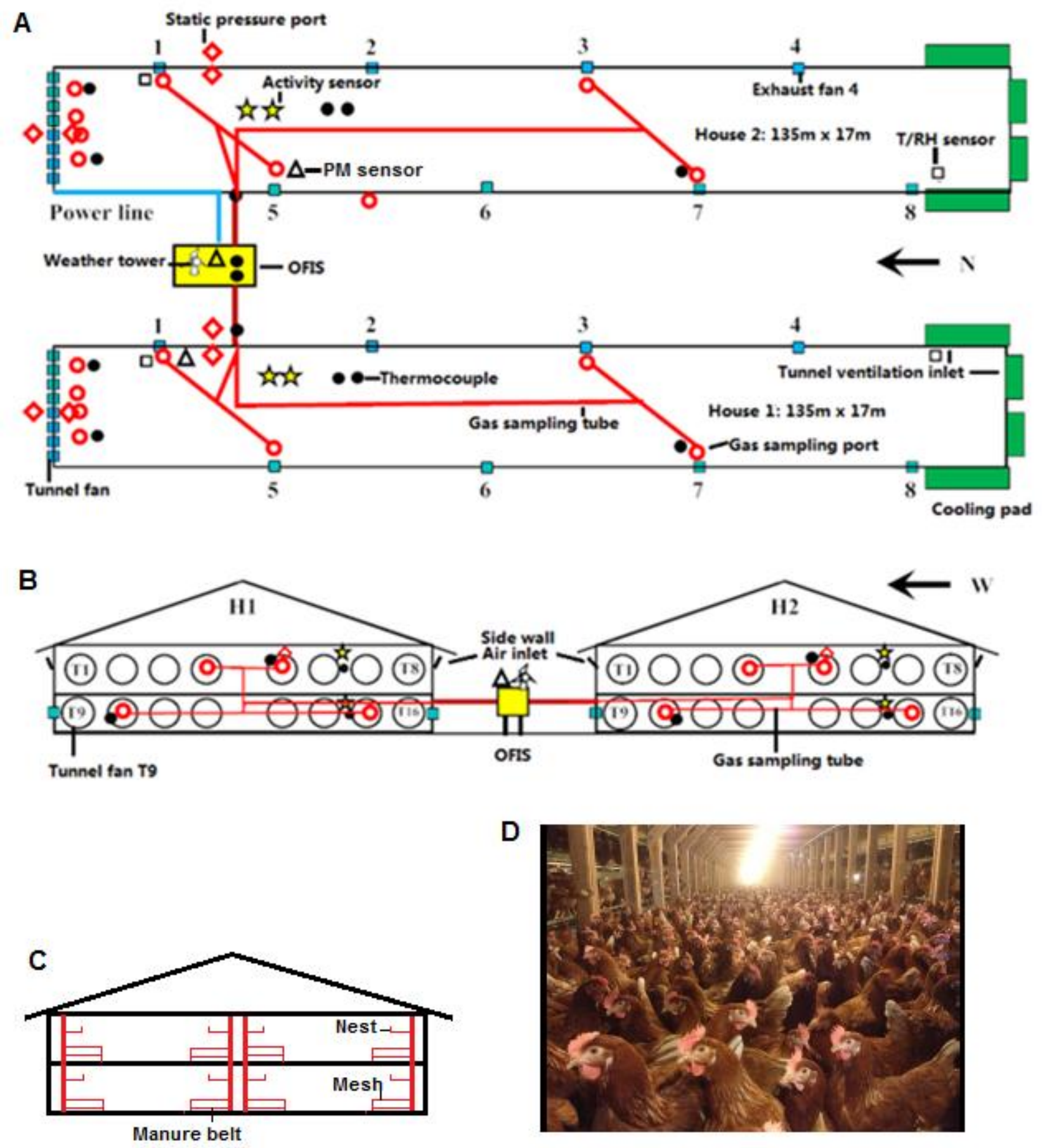

Fig. 1. Schematic of measurement and sampling locations of the monitored cage-free layer houses: (A)

plane view and (B) end view; (C) schematic of cross section of layer houses, and (D) a photo of layers in a layer house. 
The house temperature was maintained between 22.2 and $25.6^{\circ} \mathrm{C}$. House ventilation was provided with eight 91-cm single speed side wall fans (AT36Z1, Aerotech, Mason, MI) in the first floor side walls, and sixteen 130-cm single speed tunnel fans (VX511F1CR, Aerotech, Mason, MI) fixed in two rows in the north end wall (Fig. 1B). Eight evaporative cooling pads were installed in the southern end and two side walls. Ventilation air entered the second floor through 66 side wall inlets (33 each side, each measuring 122 $\mathrm{cm} \mathrm{L} \times 18 \mathrm{~cm} \mathrm{H}$ ) evenly distributed along the eaves of both side walls. The 24 fans were operated in 12 stages in three ventilation modes (VM) as shown in Table 1 to provide the suitable temperature for bird comfort as shown by the set points as recommended and applied in egg production facilities. In VM 3, if the house temperature continued to rise, the cooling pads would be applied. The environmental control and data acquisition systems recorded static pressure of the hen houses, indoor air temperature and relative humidity, cooling cell water pump on/off, egg production, and outdoor temperature and relative humidity every minute.

Table 1. Ventilation stages and temperature set points in both layer houses.

\begin{tabular}{cccc}
\hline Stage & $\begin{array}{c}\text { Ventilation } \\
\text { Mode }\end{array}$ & $\begin{array}{c}\text { Set point } \\
\left({ }^{\circ} \mathbf{C}\right)\end{array}$ & Added Fan ID \\
\hline 1 & 1 & 24.4 & Side wall fan $1,5,3,7$ \\
2 & 25.0 & Side wall fan $2,6,4,8$ \\
\hline 3 & & 25.6 & Tunnel fan 10,15 \\
4 & 26.1 & Tunnel fan 11,14 \\
5 & 26.7 & Tunnel fan 4,5 \\
6 & & 27.2 & Tunnel fan 1,8 \\
7 & & 27.8 & Tunnel fan 3,6,9,16 \\
8 & & 28.9 & Tunnel fan $2,7,12,13$ \\
\hline 9 & & $>28.9$ & Side wall fan 1,5 \\
10 & 3 & $>28.9$ & Side wall fan 2, 6 \\
11 & 328.9 & Side wall fan 3,7 \\
12 & & $>28.9$ & Side wall fan 4, 8 \\
\hline
\end{tabular}

\subsection{Monitoring Method}


A schematic of the monitoring layout for the two layer houses in plane and end-wall views is shown in Fig. $1 \mathrm{~A}$ and B. An on-farm instrument shelter (OFIS) was located between the houses (H1 and H2). Two raceways made of PVC pipes were used as bridges between OFIS and the two houses to house the sampling tubing and wires. To prevent water condensation inside the gas sampling tubing, the tubing in the two raceways were heated by temperature-controlled heating tapes.

A total of nine tubes were installed for sampling the inlet (ambient) and exhaust air for the two houses for monitoring $\mathrm{NH}_{3}$ and $\mathrm{CO}_{2}$. The first sampling tube was used to sample inlet air and its sample port was located $10 \mathrm{~cm}$ in front of the inlet of H2 (Fig. 1A). The second sampling tube drew air from side wall fans 3 and 7 which represented the pollutant concentrations in H1 stream 1 from side wall fans 3, 4, 7, and 8. (Fig. 1A). The third tube sampled exhaust air from fans 1 and 5 which represented air from $\mathrm{H} 1$ stream 2 of side wall fans $1,2,5$, and 6 . The fourth sampling tubes were used to sample the exhaust air from $\mathrm{H} 1$ tunnel fans $10 \& 15$ that represented the air exhausted out from H1 stream 3 from tunnel fans 9 through 16 (Fig. 1B). The fifth sampling tubes sampled the exhaust air from H1 tunnel fans 4 \& 5 that represented the air exhausted out from H1 stream 4 from tunnel fans 1 through 8 (Fig. 1B). Similarly, sampling tubes 6 through 9 were configured for $\mathrm{H} 2$. A total of 16 sampling ports installed in 8 exhaust sampling lines were located $0.5 \mathrm{~m}$ directly in front of the fan inside the houses (incoming airflow) at the same height as the fan hub. Each house ventilation rate was composed of streams 1 through 4.

The $\mathrm{NH}_{3}$ concentrations were measured in $\mathrm{H} 1$ from 3/1/2012 to 4/1/2013 and $\mathrm{H} 2$ from 3/17/2012 to 4/1/2013. The $\mathrm{NH}_{3}$ concentration of a house was an average concentration of the $\mathrm{NH}_{3}$ exhausted from four sampling lines. When ventilation fans were not operating, the $\mathrm{NH}_{3}$ concentration measured from that sampling line was excluded from the calculated average. Therefore, the presented $\mathrm{NH}_{3}$ concentration was the average level of $\mathrm{NH}_{3}$ ventilated out of the layer house.

The nine gas sampling lines were used to sequentially sample the inlet and outlet air by a gas sampling system (GSS). The first sampling line drew inlet air for $30 \mathrm{~min}$, and then lines 2 to 9 sequentially took house exhaust samples for $10 \mathrm{~min}$ (each) three times in one sampling cycle of 270 minutes. Therefore, in $22.5 \mathrm{~h}$, inlet and each exhaust location were sampled 5 and 15 times, respectively. The GSS delivered 
the samples to the gas analyzer. The main pump in the GSS drew sample air at approximately $4.2 \mathrm{~L} \mathrm{~min}^{-1}$ while the bypass pump purged the eight inactive sampling lines with a combined flow rate of approximately $7.2 \mathrm{~L} \mathrm{~min}^{-1}\left(0.9 \mathrm{~L} \mathrm{~min}^{-1} l \mathrm{lne}^{-1}\right)$. Air Data Acquisition and Control Software (AirDAC) developed by Ni and Heber (2010), was used to control the solenoid operation, and thus the sampling frequency for each line. All gas-sampling ports were connected with Teflon tubing (OD 3/8" and ID 1/4") to the GSS in the OFIS. Two Teflon filters (1 micron) were installed in one sampling line, at both gas sampling ports and the location before the gas sampling manifold, to prevent dust from entering the tube and the gas analyzer.

A photoacoustic IR multi-gas analyzer (INNOVA, Model 1412) was used to continuously measure, in nine sampling locations, the concentrations of $\mathrm{NH}_{3}, \mathrm{CO}_{2}$ and water vapor in the sample air. The air flow rate, relative humidity and temperature, and pressure at the manifold were measured using a flowmeter (Model 50S-10S4, McMillian Company, Georgetown, TX), a relative humidity and temperature transducer (Model HMP50YCB2A1X, Vaisala, Woburn, MA) and a pressure sensor (Model 2301002PD2F11B, Setra, Boxborough, MA), respectively.

The concentrations of $\mathrm{PM}_{10}$ and $\mathrm{PM}_{2.5}$ were measured using Beta Gage monitor (Model FH62 C-14, Thermo Environmental Instruments, Franklin, MA) that was installed inside the OFIS with its sampling inlet extending through the roof of the OFIS and $1.5 \mathrm{~m}$ above the roof of the OFIS to measure inlet concentrations. A tapered element oscillating microbalance (TEOM Model 1400a, Thermo Environmental Instruments, Franklin, MA) was located immediately upstream at the center and $0.5 \mathrm{~m}$ in the front of side wall fan 1 in $\mathrm{H} 1$ and side wall fan 5 in $\mathrm{H} 2$, as shown in Fig. 1, to measure the exhaust concentrations. The $\mathrm{PM}_{10}$ and $\mathrm{PM}_{2.5}$ were continuously monitored in the inlet and outlet air. The $\mathrm{PM}_{10}$ and $\mathrm{PM}_{2.5}$ were measured for 318 days over 396 days by alternating the $\mathrm{PM}_{10}$, and $\mathrm{PM}_{2.5}$ inlets of both TEOMs and the Beta Gage.

Temperatures at each sampling port of the nine sampling lines were measured by a thermocouple (Type T, TE Wire and Cable, Saddle Brook, NJ) and relative humidity and temperature (RHT) (RHT-WM, NOVUS, Sao Paulo, Brazil) sensors. Thermocouples located at side wall fan 7, tunnel fans 5 and 10 in both houses were used to measure temperatures for sampling lines $2,4,5,6,8$, and 9. Three RHT sensors 
located on a weather tower on the roof of the OFIS and side wall fan 1 in two houses were used to monitor the temperature and relative humidity at the inlet (ambient) and inside the two houses. The other two RHT sensors were installed close to the cooling pads to monitor the temperature and relative humidity of air coming from cooling cells. Furthermore, four thermocouples, two in each house, were used to monitor the layer room temperatures on the first and second floors. The locations of the sensors are shown in Fig. 1. Moreover, four activity sensors (VS-SRN2000N, Visonic, Tel Aviv, Israel) were installed in the four layer rooms in both houses to monitor the laying-hen activity. The activity sensor provides analog signals that are proportional to the temperature differences between the bird and the background as well as the angular velocity of birds (i.e, bird activity) (Pederson and Pederson, 1995). The signals were converted to percentage of the highest level of signals; i.e. the bird activity ranged from 0 to $100 \%$.

Differential static pressure in both houses was measured by four static pressure sensors (Model 2301002PD2F11B, Setra, Boxborough, MA) across the east wall and north end wall of H1 and H2 (Fig. 1). All static pressure sensors were installed in the OFIS. Each sensor used two tubes that extended inside and outside the house. The readings of the pressure sensors were negative under normal working status. Each pair of the side wall fans $1 \& 5,2 \& 6,3 \& 7$ and $4 \& 8$ were controlled by one relay. Each tunnel fan was controlled by one relay. Therefore, 24 fans in each house were controlled by 20 relays. To monitor fan on/off time, the 40 relays in the two houses were monitored by 40 current sensors. The cooling pads on the first and second floors were controlled by four relays and also eight current sensors were used to monitor the time of use of the cooling pads. A portable fan tester (Fan Assessment Numeration System - FANS) was used to calibrate e airflow rates of the side wall and tunnel fans (Gates et al., 2004). Fan curves were generated to calculate fan airflow rates. Details of measuring ventilation rates were reported by Lin et al. (2014).

House and location-specific PM and gas emission rates (ER) were calculated every minute with equations 1 and 2, respectively (Lin et al., 2012). The daily emission rates were calculated per laying hen, unit area, and live mass (LM). The daily emission rates were calculated by dividing the daily house-specific 
emission rate by the corresponding number of birds, the house floor area, or the number of animal units (AU; $500 \mathrm{~kg}$ live mass).

$E_{P M j}=\left[Q_{o} P_{o}\left[\frac{273+\mathrm{T}_{\mathrm{R}}}{273+T_{o}}\right]\right]\left(c_{P M o}-c_{P M i}\right)$

Where:

$E_{P M, j}=$ net $\mathrm{PM}$ emission rate $\left(\mu \mathrm{g} \mathrm{s}^{-1}\right)$

$j=2.5$ or10, representing $\mathrm{PM}_{2.5}$, or $\mathrm{PM}_{10}$

$Q_{o}=$ exhaust airflow rate $\left(\right.$ at $\left.T_{o}\right)\left(\mathrm{m}^{3} \mathrm{~s}^{-1}\right)$

$P_{o}=$ pressure of exhaust air (atm)

$T_{R}=$ instrument reference temperature $\left(T_{R}=20^{\circ} \mathrm{C}\right)$

$T_{o}=$ temperature of exhaust air $\left({ }^{\circ} \mathrm{C}\right)$

$c_{P M o}=\mathrm{PM}$ concentration $\left(\right.$ at $\left.T_{R}\right)$ in exhaust air $\left(\mu \mathrm{g} \mathrm{m}^{-3}\right)$

$c_{P M i}=$ inlet $\mathrm{PM}$ concentration $\left(\right.$ at $\left.T_{R}\right)\left(\mu \mathrm{g} \mathrm{\textrm {m } ^ { - 3 } ) .}\right.$

$E_{g a s j}=\sum_{\mathrm{k}=1}^{4} Q_{o k} \frac{P_{o} M}{R\left(273+T_{o k}\right)}\left(c_{o k}-c_{i}\right)$

where

$E_{\text {gas }, j}=$ house emission rate $\left(\mathrm{mg} \mathrm{s}^{-1}\right)$

$j=\mathrm{NH}_{3}$, or $\mathrm{CO}_{2}$

$k=$ air streams $1,2,3$, and 4 for the four sampling locations in each house

$Q_{o k}=$ exhaust airflow rate of the $k^{\text {th }}$ stream $\left(\mathrm{m}^{3} \mathrm{~s}^{-1}\right)$

$T_{o k}=$ temperature of the $k^{\text {th }}$ stream $\left({ }^{\circ} \mathrm{C}\right)$

$M=$ gas molar weight $\left(\mathrm{g} \mathrm{mol}^{-1}\right)$

$R=$ universal gas constant $\left(0.08206 \mathrm{~L} \mathrm{~atm} \mathrm{~mol}^{-1} \mathrm{~K}^{-1}\right)$

$c_{o k}=$ exhaust air concentration of the $k^{\text {th }}$ stream (ppm)

$c_{i}=$ air inlet concentration $(\mathrm{ppm})$. 


\section{Data Quality Assurance and Control}

The monitoring site setup followed a Quality Assurance Project Plan (QAPP) and standard operating procedures (Heber et al., 2007) and monitoring plan. Gas analyzer, PM monitors, and other instruments and sensors were maintained in good technical status, calibrated and checked as described in the QAPP and Lin et al. (2012). Briefly, the gas analyzer was checked weekly with zero air (EPA Certified Grade) and standard gases (EPA Primary Grade). Calibration gas was input at each sampling location to test the sampling line integrity and sampling system bias between measured concentrations and the known input gas concentration over the study period. The site computer sent a record of data every four hours by email to researchers. When problems occurred, researchers would drive to the site to solve them immediately. Therefore, apparatuses were maintained at a good working statues to assure accurate measurements.

\section{Data Processing and Analysis}

A previously developed emission data processing software, CAPECAB (Calculation of Air Pollutant Emissions from Confined Animal Buildings), was used to import data from AirDAC (LABview). A detailed description of the CAPECAB was presented by Eisentraut et al. (2004a; 2004b). The data of hen inventories, egg production, and hen live body mass taken from farm records were imported into the CAPECAB, and linearly interpolated as a continuous time series of data. The CAPECAB was also used to invalidate data due to sensor maintenance, failure, instrument stabilization, calibration, zero/span/check, etc. and facilitate correction and calculation of ventilation, concentrations and emissions (Lin et al., 2012; Lim et al., 2007; Ni et al., 2008) and report the average of data in different periods from 1 to 1440 minutes as needed. Daily and hourly means of data were only presented when valid records were more than $75 \%$ of total records (more than 1080 records for daily, and 45 records for hourly). Regression analysis was applied to determine the significance of the influencing factors such as ambient temperature, inlet temperature, seasons, and ventilation rates on the emission rates. A generalized linear model or mixed procedures were used to determine differences at a significance level of $p<0.05$ using SAS (SAS, 2009). 


\section{Results and Discussion}

The number of hens and the hourly mean $\mathrm{NH}_{3}$ concentrations in the inlet and exhaust air are shown in S2. During this period, there were 28 days on which the data were not measured because of failure of data acquisition computer or gas analyzer. The $\mathrm{H} 1$ and $\mathrm{H} 2$ had $91 \%$ and $88 \%$ of the total monitoring period with valid data.

The average inlet concentration of $\mathrm{NH}_{3}$ was $0.6 \pm 0.7 \mathrm{ppm}$ with a maximum of $5.5 \mathrm{ppm}$ during the winter period. The inlet $\mathrm{NH}_{3}$ concentration increased with the increase of $\mathrm{NH}_{3}$ concentration in the exhaust air because the exhaust air was partially drawn back into the inlet. This phenomenon was reported by other researchers during long-term monitoring (e.g., Zhao et al., 2013; Wang-Li et al., 2013).

The average and maximum concentration of $\mathrm{NH}_{3}$ in the exhaust air was, respectively, $6.0 \pm 5.8 \mathrm{ppm}$ and $27.3 \mathrm{ppm}$ in $\mathrm{H} 1$ and $5.5 \pm 5.9 \mathrm{ppm}$ and $33.5 \mathrm{ppm}$ in $\mathrm{H} 2 . \mathrm{NH}_{3}$ concentrations during May through October (warm season) were substantially lower than during other months from November to April (cool season). The $\mathrm{NH}_{3}$ concentrations in outlet air were about zero during the periods when the houses were empty (from 7/23/to 8/15, 2012 in $\mathrm{H} 1$ and from 2/12 to 3/11, 2013 in $\mathrm{H} 2$ ). The $\mathrm{NH}_{3}$ concentrations sampled from side wall fans 3 and 7 (stream 1) and 1 and 5 (stream 2) for sampling line 1 and 2 were higher than those from tunnel fans 9 and 15 (stream 3) and 4 and 5 (stream 4) because the tunnel fans were operated when the ambient temperature was high in summer.

\section{Emission Rates of Ammonia}

The complete data days (CDD) for $\mathrm{NH}_{3}$ emission rates were $94 \%$ and $95 \%$ of the total days for $\mathrm{H} 1$ and $\mathrm{H} 2$, respectively, when the houses were occupied by hens. Daily mean emission rates for each house from 4 ventilation streams are shown in S3. The missing emission rates shown in S3 were due to flock replacement or computer or analyzer failure. The $\mathrm{NH}_{3}$ emissions mainly occurred from streams 1 and 2 in the cool season, and from streams 3 and 4 in the warm season. For the entire monitoring period, the contributions to the total $\mathrm{NH}_{3}$ emissions from streams 1, 2, 3 and 4 were, respectively, $39 \%, 43 \%, 12 \%$, and 6\%. This partitioning depended on ventilation mode and ambient temperature. 
The data in S3 show that the emission rates were lower in the warm season than in the cool season. This might be due to the higher drying rates of manure and formation of a crust layer on the manure during the summer season that resulted from the higher ventilation rate and lower relative humidity in the ventilating air. The fast drying of manure in the summer months could reduce the enzymatic and microbial degradation rate of uric acid and undigested protein (Groot Koerkamp, 1994). Uric acid and undigested protein are the main precursors of $\mathrm{NH}_{3}$ in manure. It can also be seen from the data in $\mathrm{S} 3$ that the $\mathrm{NH}_{3}$ emission rates during March and April of 2012 for $\mathrm{H} 2$ were much higher than those for $\mathrm{H} 1$ in the same period. This might be due to the introduction of a new flock in $\mathrm{H} 2$ during that period and the higher number of hens in H2. The number of hens during this period is shown in S2. Lohmann Teirzucht (2011) stated that crude protein contents in the diets of young hens were $18 \%$, which is higher than that $(15 \%)$ for the old hens. The higher protein contents in the diet of the young hens increase the nitrogen content in manure and litter, which would further lead to increased $\mathrm{NH}_{3}$ volatilization and thus emission.

\section{Table 2}

Daily mean specific $\mathrm{NH}_{3}$ emission rates and complete data hours (CDH) and complete data days (CDD) for both studied houses.

\begin{tabular}{clcccc}
\hline \multirow{2}{*}{ House } & Emission Unit & $\begin{array}{c}\text { Hourly } \\
\mathrm{CDH}\end{array}$ & Mean & CDD & Mean \\
\hline $\mathrm{H} 1$ & $\mathrm{~kg} \mathrm{~d}^{-1}$ house $^{-1}$ & 8344 & $10.0 \pm 8.5$ & 348 & $10.0 \pm 7.2$ \\
& $\mathrm{~g} \mathrm{~d}^{-1} \mathrm{~m}^{2}$ & 8344 & $2.2 \pm 1.9$ & 348 & $2.2 \pm 1.6$ \\
& $\mathrm{~g} \mathrm{~d}^{-1} \mathrm{hen}^{-1}$ & 8344 & $0.29 \pm 0.2$ & 348 & $0.29 \pm 0.2$ \\
& $\mathrm{~g} \mathrm{~d}^{-1} \mathrm{AU}^{-1}$ & 8344 & $81.4 \pm 68.5$ & 348 & $81.1 \pm 57.8$ \\
\hline $\mathrm{H} 2$ & $\mathrm{~kg} \mathrm{~d}^{-1}$ house $^{-1}$ & 7778 & $9.7 \pm 10.3$ & 323 & $9.7 \pm 9.1$ \\
& $\mathrm{~g} \mathrm{~d}^{-1} \mathrm{~m}^{2}$ & 7778 & $2.1 \pm 2.3$ & 323 & $2.1 \pm 2.0$ \\
& $\mathrm{~g} \mathrm{~d}^{-1}$ hen $^{-1}$ & 7778 & $0.30 \pm 0.3$ & 324 & $0.30 \pm 0.3$ \\
& $\mathrm{~g} \mathrm{~d}^{-1} \mathrm{AU}^{-1}$ & 7778 & $86.0 \pm 86.4$ & 323 & $85.8 \pm 76.9$ \\
\hline \multirow{2}{*}{ Average } & $\mathrm{kg} \mathrm{d}^{-1}$ house $^{-1}$ & 16122 & $9.9 \pm 9.4$ & 671 & $9.8 \pm 8.2$ \\
& $\mathrm{~g} \mathrm{~d}^{-1} \mathrm{~m}^{2}$ & 16122 & $2.2 \pm 2.1$ & 671 & $2.2 \pm 1.8$ \\
& $\mathrm{~g} \mathrm{~d}^{-1} \mathrm{hen}^{-1}$ & 16122 & $0.29 \pm 0.3$ & 672 & $0.29 \pm 0.2$ \\
& $\mathrm{~g} \mathrm{~d}^{-1} \mathrm{AU}^{-1}$ & 16122 & $83.6 \pm 77.7$ & 671 & $83.3 \pm 67.6$ \\
\hline
\end{tabular}


Fig. 2 shows the monthly average $\mathrm{NH}_{3}$ emission rates and inlet temperature, humidity ratio and ventilation rate in warm and cool seasons for the two houses. The emission rates were higher in the cool season than that in the warm season. The monthly inlet temperature, ventilation rate and room air humidity ratio in the warm season were higher than those in the cool season. The higher ventilation rate in the warm season made manure and litter drier than that in the cool season. The higher temperature facilitated the increase of emission rates. Consequently, the emission rate was lower in the warm season. Lower $\mathrm{NH}_{3}$ emission rates in the warm season had also been reported for high-rise layer houses on the same farm (Lin et al., 2012). Liang et al. (2013) also reported a decreased ammonia emission rates with increased exhaust temperature in high-rise layer houses.

The $\mathrm{NH}_{3}$ emission rates expressed in different units are shown in Table 2. The average $\mathrm{NH}_{3}$ emission rates for both houses were essentially the same: 0.29 and $0.30 \mathrm{~g} \mathrm{~d}^{-1} \mathrm{hen}^{-1}$ for $\mathrm{H} 1$ and $\mathrm{H} 2$, respectively. These emission rates are similar to the value $\left(0.28 \mathrm{~g} \mathrm{~d}^{-1} \mathrm{hen}^{-1}\right)$ reported by $\mathrm{Ni}$ et al. (2010) during two-year emission monitoring in two manure-belt layer houses. Shepherd et al. (2015) reported an emission rate of 0.082 and $0.054 \mathrm{~g} \mathrm{~d}^{-1} \mathrm{hen}^{-1}$ in manure-belt conventional cage and enriched colony houses, respectively. The emission rates observed in this study were higher than the values of 0.14 and $0.112 \mathrm{~g} \mathrm{~d}^{-1}$ $\operatorname{hen}^{-1}$ for aviary houses reported by Zhao et al. (2013) and Shepherd et al. (2015), respectively. The higher emissions from aviary house could be attributed to the fact that part of manure in aviary houses is mixed with litter and stored in the house for whole production cycle. The lower emission rates in the aviary house than the cage-free could be due to the presence the manure belts that frequently remove most of manure, and the blowers present over manure belts that facilitated the manure drying. Albeit the reduced $\mathrm{NH}_{3}$ emissions, blowers consume $50 \%$ of the total electricity used for the house (Hayes et al., 2014). Compared with manure-belt houses that have a higher stocking density $\left(432 \mathrm{~cm}^{2} /\right.$ hen or $\left.67 \mathrm{in}^{2} / \mathrm{hen}\right)$, cagefree houses monitored in the current study had higher emission rates because about $25 \%$ of manure was deposited and stayed on the litter for the entire production cycle.

The emission rates of the cage-free houses observed in the current study were much lower than the values of 0.95 and $0.61 \mathrm{~g} \mathrm{~d}^{-1}$ hen ${ }^{-1}$, respectively in high-rise houses reported by Lin et al. (2012) and Wang- 
Li et al. (2013) because in the latter cases manure was stored in the lower level of the houses for 6-12 months.

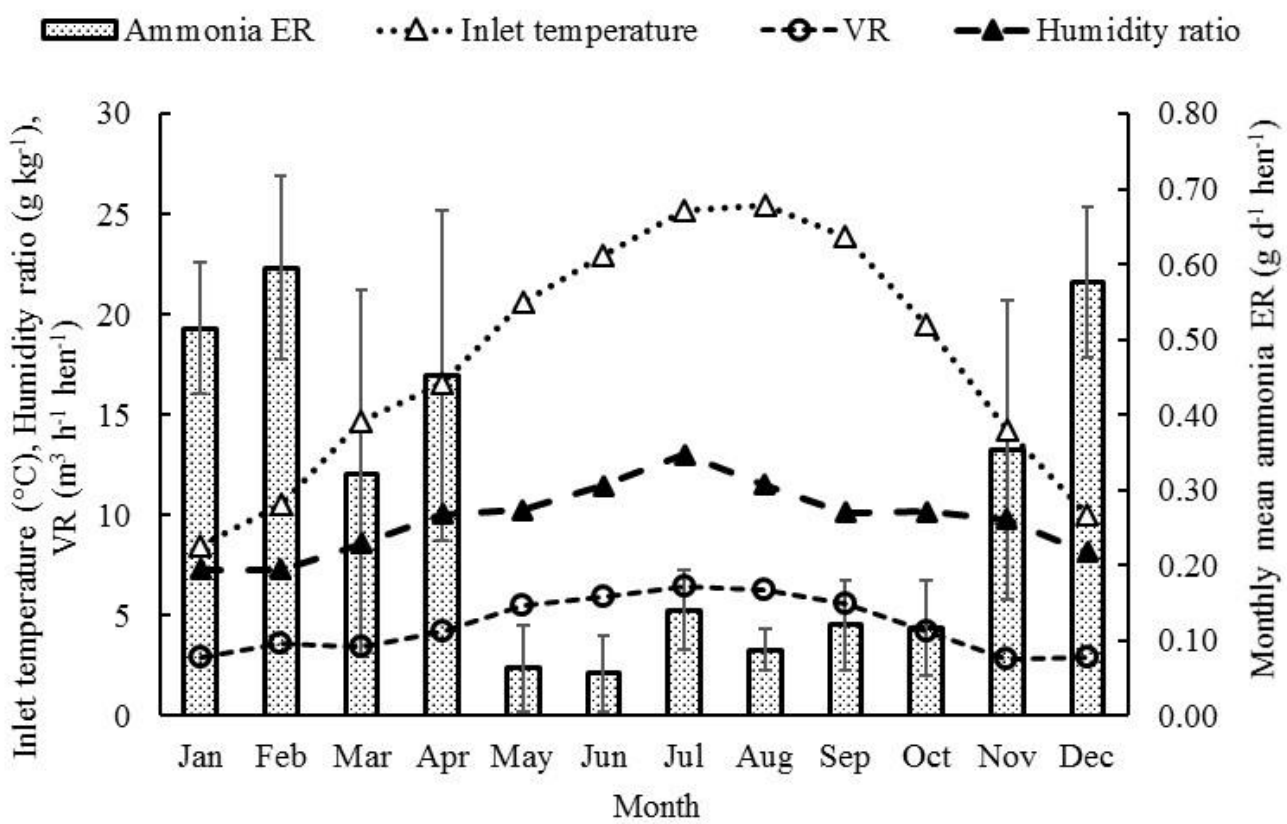

Fig. 2. Monthly average $\mathrm{NH}_{3}$ emission rates (ER) and inlet temperature, humidity ratio and ventilation rate (VR) in warm and cool seasons for the two houses (Y error bars are standard deviations).

$\mathrm{NH}_{3}$ emission rates are affected by the length of time that manure stays on the collection belt. The manure on the belts was cleaned at 11:00 am every Monday, Wednesday and Friday. Hence, the manure age was up to $48 \mathrm{~h}$ for the Wednesday and Friday removal and up to $72 \mathrm{~h}$ for the Monday removal. Fig. 3 shows the hourly average $\mathrm{NH}_{3}$ emission rates based on 15,906 hourly data points from the two houses. Both emission rates had a sinusoidal variation pattern which was similar to the variation in temperature for the cool or warm seasons. This means that the inlet (ambient) temperature is a key factor for influencing the emission rate of $\mathrm{NH}_{3}$. 


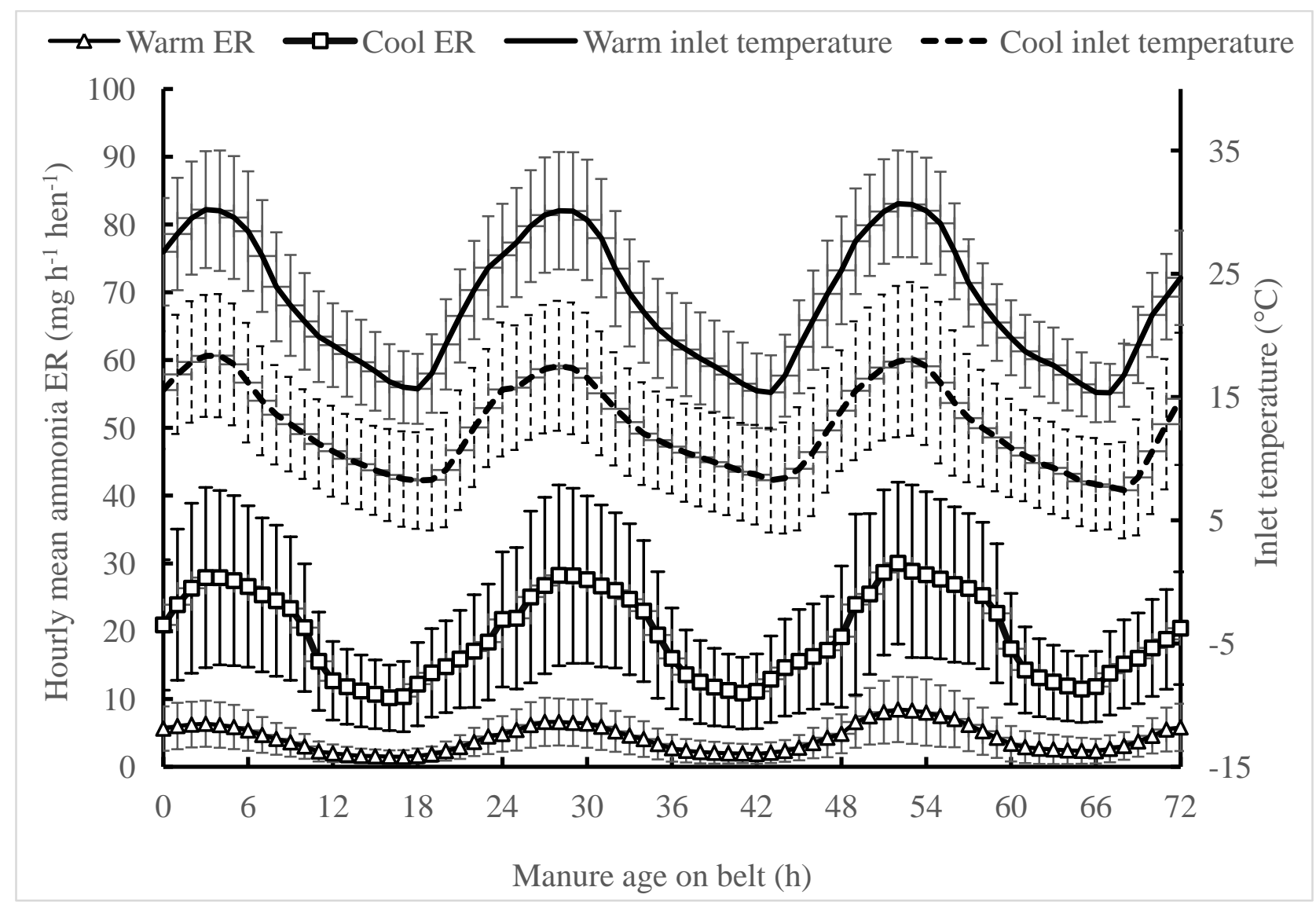

Fig. 3. Hourly average $\mathrm{NH}_{3}$ emission rates (ER) and age of manure ( 0 to $72 \mathrm{~h}$ ) on belts under cool and warm climatic conditions. The Y error bars are standard deviations.

The $\mathrm{NH}_{3}$ emission rates increased with the increase of manure age on the belts in both cool and warm seasons. The emission rates for the manure left for 1,2 , and $3 \mathrm{~d}$ in cool season were $0.45,0.46$, and $0.49 \mathrm{~g} \mathrm{~d}^{-1} \mathrm{hen}^{-1}$, respectively. There were no significant differences in the emission rates between 1 and $2 \mathrm{~d}$. However, there were significant differences in the emission rates between $3 \mathrm{~d}$ and both 1 and $2 \mathrm{~d}(\mathrm{p}<0.01)$. Although the emission rates in warm season were lower than those measured in the cool season, the emission rates were $0.09,0.10$, and $0.12 \mathrm{~g} \mathrm{~d}^{-1} \mathrm{hen}^{-1}$, respectively, and significantly different.

Fig. 4 shows the relationship between $\mathrm{NH}_{3}$ emission rates and house inlet air temperature using the diurnal emission rate data. High correlation $\left(R^{2} \geq 0.86\right)$ was found for the linear regression between the $\mathrm{NH}_{3}$ emission rates and inlet temperature. 


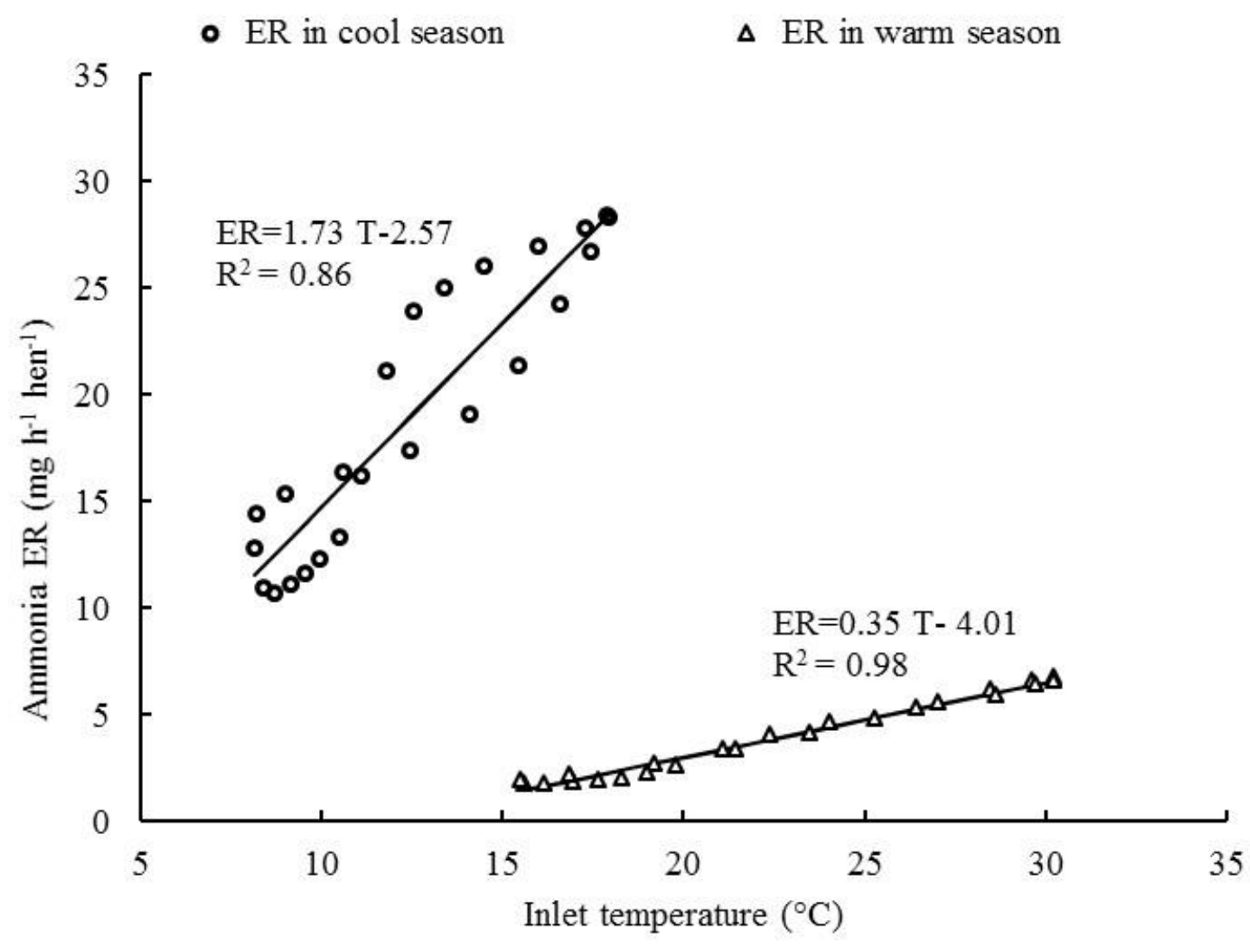

Fig. 4. Relationship between hourly $\mathrm{NH}_{3}$ emission rates (ER) and inlet air temperature in cool and warm seasons.

\section{Concentrations and Emission Rates of Carbon Dioxide}

Daily mean $\mathrm{CO}_{2}$ concentrations, emission and ventilation rates in both houses during the monitoring period (3/1/2012 to 4/1/2013) are shown S4. The inlet concentrations slightly varied during the monitoring period. The exhausted $\mathrm{CO}_{2}$ concentration was higher in the cool season than that in the warm season, attributable to higher different ventilation rates for the warm season. Emission rates of $\mathrm{CO}_{2}$ were lower during the period of August to September for $\mathrm{H} 1$ and in March for $\mathrm{H} 2$ because hens in both houses were young during these periods. Young hens have lower body weight and exhale less $\mathrm{CO}_{2}$. Higher ventilation 
rates were applied during the period of $1 / 27 / 2013$ to $2 / 23 / 2013$ in $\mathrm{H} 1$, which resulted in reduced $\mathrm{CO}_{2}$ concentrations.

The $\mathrm{CO}_{2}$ emission rates increased from 3:00 AM to 8:00 AM, and remained constant until 8:00 PM, and then decreased (Fig. 5). The higher emission rates presumably arose from increased bird activity and exercise. Further, the emission rates in $\mathrm{H} 2$ were greater than in $\mathrm{H} 1$ due to the higher ventilation rates in $\mathrm{H} 2$ than in $\mathrm{H} 1$ while the concentrations in both houses were similar (Fig. 7). For both houses, $\mathrm{CO}_{2}$ concentrations increased from 3:00 to 6:00 AM, and then slightly decreased and remained constant. Hayes et al. (2013) delineated that latent heat production was related to hens metabolic extent and light and dark time. The $\mathrm{CO}_{2}$ concentrations were higher during the light than during dark periods. Table 3 shows the complete data days, daily average $\mathrm{CO}_{2}$ concentration and emission rate for the two houses. The average emission rate of $\mathrm{CO}_{2}$ was approximately $89.90 \mathrm{~g} \mathrm{~d}^{-1} \mathrm{hen}^{-1}$ that was higher than the values of 74.0, 68.3, and $74.4 \mathrm{~g} \mathrm{~d}^{-1} \mathrm{hen}^{-1}$ reported by Shepherd et al. (2015) for Lohman white hens in aviary, conventional cage, and enriched colony housing, respectively. However, the measured emission rates in the current study was very close to the value (91.4 $\left.\mathrm{g} \mathrm{d}^{-1} \mathrm{hen}^{-1}\right)$ that was measured by Lin et al. (2012) in high-rise house for Lohman white hens. 

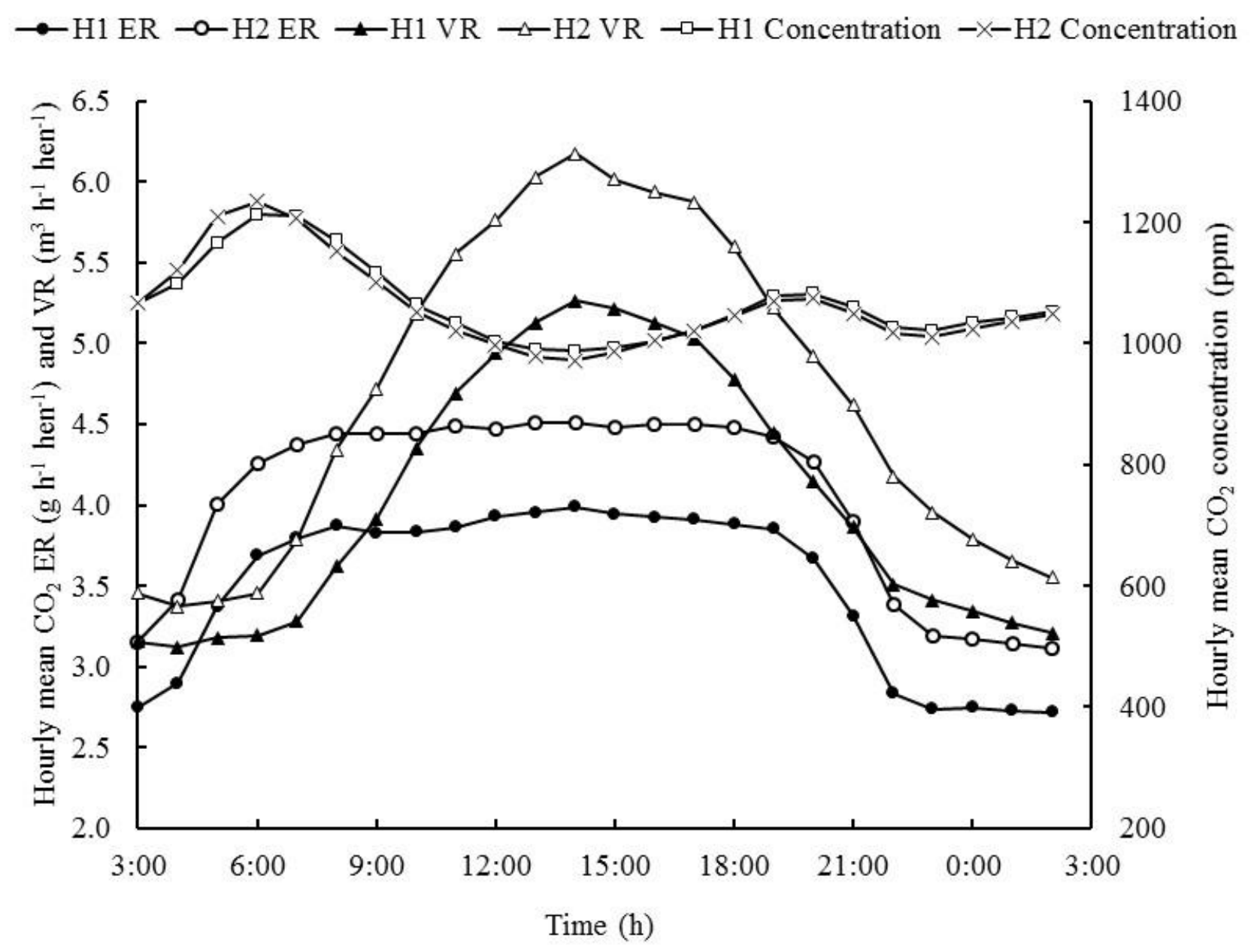

Fig. 5. Hourly average $\mathrm{CO}_{2}$ concentration, emission rate (ER), and ventilation rate (VR) of both cage-free layer houses with Lohman brown hens. 
Table 3

Mean concentrations and emission rates of $\mathrm{CO}_{2}$ and complete data days in both studied houses.

\begin{tabular}{llcc} 
Location & \multicolumn{1}{c}{ Unit } & CDD & Mean \\
\hline Concentration & & & \\
\hline Inlet & $\mathrm{ppm}$ & 361 & $509 \pm 45$ \\
House 1 & $\mathrm{ppm}$ & 360 & $894 \pm 173$ \\
House 2 & $\mathrm{ppm}$ & 363 & $944 \pm 194$ \\
Overall & $\mathrm{ppm}$ & 723 & $919 \pm 185$ \\
\hline Emission rate & & & \\
\hline House 1 & $\mathrm{Mg} \mathrm{d}^{-1} \mathrm{house}^{-1}$ & 375 & $2.66 \pm 0.79$ \\
& $\mathrm{~kg} \mathrm{~d}^{-1} \mathrm{~m}^{-2}$ & 375 & $0.59 \pm 0.17$ \\
& $\mathrm{~g} \mathrm{~d}^{-1} \mathrm{hen}^{-1}$ & 353 & $82.79 \pm 14.81$ \\
& $\mathrm{~kg} \mathrm{~d}^{-1} \mathrm{AU}^{-1}$ & 353 & $23.46 \pm 3.77$ \\
\hline House 2 & $\mathrm{Mg} \mathrm{d}^{-1} \mathrm{house}^{-1}$ & 362 & $3.11 \pm 0.95$ \\
& $\mathrm{~kg} \mathrm{~d}^{-1} \mathrm{~m}^{-2}$ & 362 & $0.69 \pm 0.21$ \\
& $\mathrm{~g} \mathrm{~d}^{-1} \mathrm{hen}^{-1}$ & 342 & $97.24 \pm 16.18$ \\
& $\mathrm{~kg} \mathrm{~d}^{-1} \mathrm{AU}^{-1}$ & 342 & $28.51 \pm 4.35$ \\
\hline $\mathrm{Mg} \mathrm{d}^{-1} \mathrm{house}^{-1}$ & 737 & $2.88 \pm 0.90$ \\
& $\mathrm{~kg} \mathrm{~d}^{-1} \mathrm{~m}^{-2}$ & 737 & $0.63 \pm 0.20$ \\
& $\mathrm{~g} \mathrm{~d}^{-1} \mathrm{hen}^{-1}$ & 695 & $89.90 \pm 17.09$ \\
& $\mathrm{~kg} \mathrm{~d}^{-1} \mathrm{AU}^{-1}$ & 695 & $25.95 \pm 4.78$ \\
\hline Average & &
\end{tabular}

\section{Concentrations and Emission Rates of Particulate Matter $\left(\mathbf{P M}_{10}\right.$ and $\left.\mathbf{P M}_{2.5}\right)$}

$\mathrm{PM}_{10}$ and $\mathrm{PM}_{2.5}$ concentrations were monitored from $3 / 1 / 2012$ to $2 / 3 / 2013$. The daily mean $\mathrm{PM}_{10}$ concentrations at the inlet and outlet air and emission rates for the whole period are shown in S5. The concentrations of $\mathrm{PM}_{2.5}$ in the inlet air were very low with an average concentration of $137.3 \pm 87.6 \mu \mathrm{g} \mathrm{m}^{-3}$ which was lower than that $\left(410 \mu \mathrm{g} \mathrm{m}^{-3}\right)$ measured in the aviary house (Zhao et al., 2015b). The indoor concentrations of $\mathrm{PM}_{10}$ ranged from 284 to 5012 and averaged $1576 \pm 656 \mu \mathrm{g} \mathrm{m}^{-3}$ (Table 4). The daily mean $\mathrm{PM}_{10}$ concentration in this study was 1.7 and 1.9 times greater than those found in manure-belt and highrise layer houses (588 and $546 \mu \mathrm{g} \mathrm{m}^{-3}$, respectively) (Ni et al., 2012). The determined $\mathrm{PM}_{10}$ concentration in the current study was 2.4 times greater than that $\left(463 \mu \mathrm{g} \mathrm{m}^{-3}\right)$ reported by Li et al. (2013) for high-rise layer 
houses. However, this value was lower than that $\left(3950 \mu \mathrm{g} \mathrm{m}^{-3}\right)$ measured by Zhao et al. (2015b) in the aviary house. The High value in the latter study might be due to the low ventilation rate $\left(1.99 \mathrm{~m}^{3} \mathrm{hen}^{-1} \mathrm{~h}^{-1}\right)$ applied under Midwest weather conditions. The higher $\mathrm{PM}_{10}$ concentrations measured in the current study might be attributed to the fact that hens in the cage-free houses could freely access the litter on the floor, scratch and stir considerable amount of dust into the air. The higher rate of dust generation is a shortcoming of the cage-free houses.

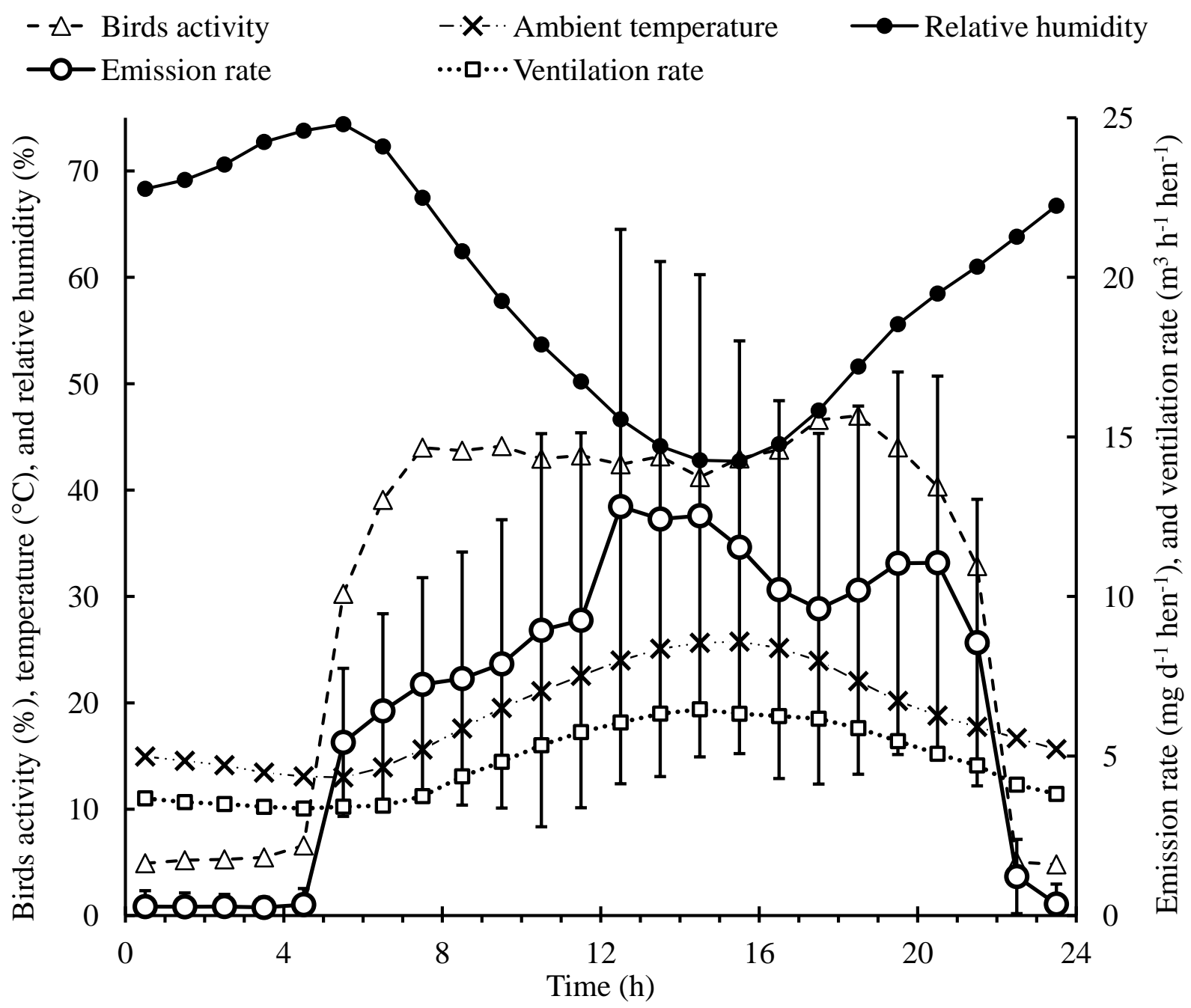

Fig. 6. Hourly mean emission rates of $\mathrm{PM}_{10}$ with error bars of standard deviation, bird activity, inlet air temperature and relative humidity, and house ventilation rate. Lights came on at 5 AM and were turned off at $9 \mathrm{PM}$. 
The daily mean emission rate of $\mathrm{PM}_{10}$ in $\mathrm{H} 1$ varied more strongly than that in $\mathrm{H} 2$ during the period from late August to the end of December (S5) due to loading new laying-hens on 8/15/2012. Both houses had similar emission rates of $\mathrm{PM}_{10}$ (Table 4). The hourly mean $\mathrm{PM}_{10}$ emission rate was calculated from the 11,463 hourly data as shown in Fig. 6. The emission rates during layer activity or light hours (from 5:00 AM to 9:00 PM) were noticeably greater than the emission rates determined during the sleeping or dark hours (from 9:00 PM to 5:00 AM). Hen activities, ambient temperature and ventilation rates were positively affecting $\mathrm{PM}_{10}$ emission rate. McQuitty et al. (1985) found that the emissions of particulate matter increased with the increase of bird activities in three caged-layer houses. However, ambient air relative humidity suppressed $\mathrm{PM}_{10}$ emissions. The overall average emission rate of $\mathrm{PM}_{10}$ for both houses was $163 \pm 63 \mathrm{mg} \mathrm{d}^{-1} \mathrm{hen}^{-1}$ (Table 4). The determined average emission rate was 3.9 times greater than that (33.4 $\mathrm{mg} \mathrm{d}^{-1} \mathrm{hen}^{-1}$ ) reported by Lin et al. (2012) and 8.2 times greater than that (17.8 $\left.\mathrm{mg} \mathrm{d}^{-1} \mathrm{hen}^{-1}\right)$ reported by Li et al. (2013) for high-rise layer houses. Shepherd et al. (2015) reported $\mathrm{PM}_{10}$ emission rates of 100.3, 15.7, and $15.6 \mathrm{mg} \mathrm{d}^{-1} \mathrm{hen}^{-1}$, respectively, for aviary, conventional cage, and enriched colony houses with Lohman white hens. Ni et al. (2010) reported an emission rate of $17.1 \mathrm{mg} \mathrm{d}^{-1} \mathrm{hen}^{-1}$ in a conventional cage house.

Table 4

Hourly and daily means of concentrations, emission rates, complete data hours (CDH) and complete data days (CDD) of $\mathrm{PM}_{10}$ for both studied houses.

\begin{tabular}{llcccc}
\hline \multicolumn{1}{c}{ Location } & \multicolumn{1}{c}{ Unit } & CDH & Hourly & CDD & Daily \\
\hline Concentration & & & & & \\
Inlet & $\mu \mathrm{g} \mathrm{m}^{-3}$ & 7034 & $137 \pm 150$ & 290 & $137 \pm 88$ \\
$\mathrm{H} 1$ & $\mu \mathrm{g} \mathrm{m}^{-3}$ & 5317 & $1628 \pm 1525$ & 219 & $1628 \pm 728$ \\
$\mathrm{H} 2$ & $\mu \mathrm{g} \mathrm{m}^{-3}$ & 6666 & $1543 \pm 1313$ & 278 & $1535 \pm 590$ \\
Overall & $\mu \mathrm{g} \mathrm{m}^{-3}$ & 11983 & $1581 \pm 1412$ & 497 & $1576 \pm 655$ \\
\hline Emission rate & & & & & \\
& $\mathrm{kg} \mathrm{d}^{-1}$ house $^{-1}$ & 5174 & $5.7 \pm 6.0$ & 219 & $5.6 \pm 2.6$ \\
$\mathrm{H} 1$ & $\mathrm{mg} \mathrm{d}^{-1} \mathrm{~m}^{-2}$ & 5173 & $1256 \pm 1323$ & 219 & $1234.7 \pm 568.6$ \\
& $\mathrm{mg} \mathrm{d}^{-1} \mathrm{hen}^{-1}$ & 5171 & $168 \pm 175$ & 219 & $165.0 \pm 76.1$
\end{tabular}




\begin{tabular}{llcccc} 
& & 5173 & $48 \pm 50$ & 219 & $46.8 \pm 21.2$ \\
\hline \multirow{4}{*}{$\mathrm{g} \mathrm{d}$} & $\mathrm{kg} \mathrm{d}^{-1} \mathrm{AU}^{-1}$ & 6.6 & $5.6 \pm 4.9$ & 278 & $5.5 \pm 1.7$ \\
& $\mathrm{mg} \mathrm{d}^{-1} \mathrm{~m}^{-2}$ & 6568 & $1228 \pm 1079$ & 278 & $1204.6 \pm 374.5$ \\
& $\mathrm{mg} \mathrm{d}^{-1} \mathrm{hen}^{-1}$ & 6572 & $165 \pm 144$ & 278 & $162.0 \pm 49.4$ \\
& $\mathrm{~g} \mathrm{~d}^{-1} \mathrm{AU}^{-1}$ & 6565 & $48 \pm 42$ & 278 & $47.4 \pm 14.8$ \\
\hline \multirow{3}{*}{ Overall } & $\mathrm{kg} \mathrm{d}^{-1}$ house & 11.7 & $5.6 \pm 5.4$ & 497 & $5.5 \pm 2.1$ \\
& $\mathrm{mg} \mathrm{d}^{-1} \mathrm{~m}^{-2}$ & 11741 & $1240 \pm 1192$ & 497 & $1217.8 \pm 469.7$ \\
& $\mathrm{mg} \mathrm{d}^{-1} \mathrm{hen}^{-1}$ & 11743 & $166 \pm 158$ & 497 & $163.3 \pm 62.5$ \\
& $\mathrm{~g} \mathrm{~d}^{-1} \mathrm{AU}^{-1}$ & 11738 & $48 \pm 46$ & 497 & $47.2 \pm 17.9$ \\
\hline
\end{tabular}

The $\mathrm{PM}_{2.5}$ were monitored from $3 / 6 / 2012$ to $4 / 2 / 2012$. Table 5 shows the hourly means of $\mathrm{PM}_{2.5}$ concentration and emission rates measured in a total of 1054 hours. The daily average concentration of $\mathrm{PM}_{2.5}$ in both houses ranged from 42.7 to $683.8 \mu \mathrm{g} \mathrm{m} \mathrm{m}^{-3}$ and averaged at $263.5 \mu \mathrm{g} \mathrm{m} \mathrm{m}^{-3}$. The $\mathrm{PM}_{2.5}$ concentrations in $\mathrm{H} 2$ were higher than those in $\mathrm{H} 1$ because the layers in $\mathrm{H} 2$ were younger and might have been more active than those in $\mathrm{H} 1$. The $\mathrm{PM}_{2.5}$ emission rates ranged from 3.1 to $53.4 \mathrm{mg} \mathrm{d}^{-1}$ hen $^{-1}$ and averaged $19.9 \mathrm{mg} \mathrm{d}^{-1} \mathrm{hen}^{-1}$. The latter was 2.4 times greater than that $\left(5.9 \mathrm{mg} \mathrm{d}^{-1} \mathrm{hen}^{-1}\right)$ reported by Lin et al. (2012) and much greater than that $\left(0.38 \mathrm{mg} \mathrm{d}^{-1} \mathrm{hen}^{-1}\right)$ reported by $\mathrm{Li}$ et al. (2013) for high-rise layer houses. Shepherd et al. (2015) measured emission rates of 8.8, 0.90, and $1.7 \mathrm{mg} \mathrm{d}^{-1} \mathrm{hen}^{-1}$, respectively for aviary, conventional cage, and enriched colony with Lohman white hens. Ni et al. (2010) reported an emission rate of $0.05 \mathrm{mg} \mathrm{d}^{-1} \mathrm{hen}^{-1}$ in a conventional cage house.

Table 5

Hourly and daily means of concentrations, emission rates and complete data hours (CDH) and complete data days (CDD) of $\mathrm{PM}_{2.5}$ for both studied houses.

\begin{tabular}{llcccc}
\hline \multicolumn{1}{c}{ Location } & \multirow{2}{*}{ Unit } & CDH & Mean hourly & Mean daily \\
\hline Concentration & & & & & \\
\hline Inlet & $\mu \mathrm{g} \mathrm{m}^{-3}$ & 692 & $12.7 \pm 7.6$ & 28 & $12.7 \pm 3.2$ \\
$\mathrm{H} 1$ & $\mu \mathrm{g} \mathrm{m}^{-3}$ & 468 & $148.6 \pm 132.4$ & 22 & $125.8 \pm 79.2$ \\
$\mathrm{H} 2$ & $\mu \mathrm{g} \mathrm{m}^{-3}$ & 600 & $417.2 \pm 291.0$ & 27 & $375.7 \pm 138.6$ \\
Overall & $\mu \mathrm{g} \mathrm{m}^{-3}$ & 1068 & $299.5 \pm 270.1$ & 49 & $263.5 \pm 170.0$ \\
\hline Emission rate & & & & \\
\hline
\end{tabular}




\begin{tabular}{|c|c|c|c|c|c|}
\hline \multirow{4}{*}{$\mathrm{H} 1$} & $\mathrm{~g} \mathrm{~d}^{-1}$ house $^{-1}$ & 457 & $324.6 \pm 282.5$ & 21 & $278.1 \pm 167.9$ \\
\hline & $\mathrm{mg} \mathrm{d}^{-1} \mathrm{~m}^{-2}$ & 457 & $71.5 \pm 62.2$ & 21 & $61.2 \pm 37.0$ \\
\hline & $\mathrm{mg} \mathrm{d}^{-1} \mathrm{hen}^{-1}$ & 457 & $9.9 \pm 8.6$ & 21 & $8.5 \pm 5.1$ \\
\hline & $\mathrm{g} \mathrm{d}^{-1} \mathrm{AU}^{-1}$ & 457 & $2.7 \pm 2.4$ & 21 & $2.3 \pm 1.4$ \\
\hline \multirow{4}{*}{$\mathrm{H} 2$} & $\mathrm{~g} \mathrm{~d}^{-1}$ house $^{-1}$ & 597 & $1211.4 \pm 981.5$ & 27 & $1085.7 \pm 442.1$ \\
\hline & $\mathrm{mg} \mathrm{d}^{-1} \mathrm{~m}^{-2}$ & 597 & $266.7 \pm 216.1$ & 27 & $239.0 \pm 97.3$ \\
\hline & $\mathrm{mg} \mathrm{d}^{-1}$ hen $^{-1}$ & 597 & $32.2 \pm 26.1$ & 27 & $28.8 \pm 11.7$ \\
\hline & $\mathrm{g} \mathrm{d}^{-1} \mathrm{AU}^{-1}$ & 597 & $8.9 \pm 7.3$ & 27 & $8.0 \pm 3.3$ \\
\hline \multirow{4}{*}{ Overall } & $\mathrm{g} \mathrm{d}^{-1}$ house $^{-1}$ & 1054 & $826.9 \pm 879.3$ & 48 & $732.4 \pm 533.0$ \\
\hline & $\mathrm{mg} \mathrm{d}^{-1} \mathrm{~m}^{-2}$ & 1054 & $182.0 \pm 193.6$ & 48 & $161.2 \pm 117.3$ \\
\hline & $\mathrm{mg} \mathrm{d}^{-1} \mathrm{hen}^{-1}$ & 1054 & $22.5 \pm 23.2$ & 48 & $19.9 \pm 13.8$ \\
\hline & $\mathrm{g} \mathrm{d}^{-1} \mathrm{AU}^{-1}$ & 1054 & $6.2 \pm 6.5$ & 48 & $5.5 \pm 3.8$ \\
\hline
\end{tabular}

\section{Conclusions}

Concentrations and emission rates of $\mathrm{NH}_{3}, \mathrm{CO}_{2}, \mathrm{PM}_{10}$ and $\mathrm{PM}_{2.5}$ of two cage-free layer houses in California were continually monitored for 13 months. Daily average emission rates of $\mathrm{NH}_{3}$ and $\mathrm{CO}_{2}$ were determined to be $0.29 \pm 0.67 \mathrm{~g} \mathrm{~d}^{-1} \mathrm{hen}^{-1}\left(83.3 \pm 67.6 \mathrm{~g} \mathrm{~d}^{-1} \mathrm{AU}^{-1}\right)$ and $89.9 \pm 17.1 \mathrm{~g} \mathrm{~d}^{-1} \mathrm{hen}^{-1}\left(26.0 \pm 4.8 \mathrm{~kg} \mathrm{~d}^{-1}\right.$ $\mathrm{AU}^{-1}$ ), respectively. These $\mathrm{NH}_{3}$ emission rates were similar to the published values for manure-belt layer houses but greater than the published values for aviary houses. The $\mathrm{NH}_{3}$ emission rates were influenced by ambient temperature and ventilation rate, and were lower in the warm season than in the cool season because of the drier manure in the hot season. Daily average emission rates of $\mathrm{PM}_{2.5}$ and $\mathrm{PM}_{10}$ were $19.9 \pm$ $13.8 \mathrm{mg} \mathrm{d}^{-1} \operatorname{hen}^{-1}\left(5.5 \pm 3.8 \mathrm{~g} \mathrm{~d}^{-1} \mathrm{AU}^{-1}\right)$ and $163.3 \pm 62.5 \mathrm{mg} \mathrm{d}^{-1} \operatorname{bird}^{-1}\left(17.9 \pm 5.3 \mathrm{~g} \mathrm{~d}^{-1} \mathrm{AU}^{-1}\right)$, respectively. The measured $\mathrm{PM}_{10}$ concentrations were significantly higher than those in manure-belt and high-rise layer houses. The $\mathrm{PM}_{10}$ emission rates were influenced by bird activity, ambient temperature, relative humidity, and ventilation rate. 


\section{Acknowledgements}

Financial support for this study was provided by the USDA National Institute of Food and Agriculture. Inkind contribution of the monitoring equipment was provided by the Egg Industry Center located at Iowa State University, Ames, Iowa, USA.

\section{REFERENCES}

AHA. 2012a. Animal Welfare Standards for Layers- Enriched Colony Housing at www.humaneheartland.org.

AHA. 2012b. Animal Welfare Standards for Layers- Cage-Free, Aviary. \& Free Range at www.humaneheartland.org.

CA. 2013. California Health and Safety Code Section 25990-25994. http://www.leginfo.ca.gov/cgibin $/$ displaycode?section=hsc \& group=25001-26000\&file $=25990-25994$. Accessed on 8/31/2016

CDFA. 2013. New Shell Egg Food Safety Regulations. http://www.cdfa.ca.gov/ahfss/mpes/pdfs/EggSafetyRule.pdf.

Dekker, S. E. M., A. J. A. Aarnink, I. J. M. de Boer, and P. W. G. Groot Koerkamp. 2011. Emissions of ammonia, nitrous oxide, and methane from aviaries with organic laying hen husbandry. Biosystems Engineering 110(2): 123-133.

Eisentraut M.A., A. J. Heber, J.-Q. Ni (2004a) CAPECAB Part 1: Processing barn emission data, AWMA 97th Annual Conference and Exhibition, Indianapolis, IN. pp. 18. 2.

Eisentraut M.A., A. J. Heber, T.T. Lim T.T., S.J. Hoff (2004b) CAPECAB Part II: Calculating barn ventilation and emission rates, AWMA 97th Annual Conference and Exhibition, Indianapolis, IN. pp. 10.

Gates, R. S., K. D. Casey, H. Xin, E. F. Wheeler, and J. D. Simmons. 2004. Fan assessment numeration system (FANS) design and calibration specifications. Transactions of the ASAE 47(5): 1709-1715.

Gay, S. W. and K. F. Knowlton. 2013. Ammonia Emissions and Animal Agriculture. http://pubs.ext.vt.edu/442/442-110/442-110_pdf. Accessed on 9/16/2013

Greene, J. and T. Cowan. 2014. Table Egg Production and Hen Welfare: Agreement and Legislative Proposals. Congressional Research Service R42534.

Groot Koerkamp, P.W.G. 1994. Review on emissions of ammonia from housing systems for laying hens in relation to sources, processes, building design and manure handling. J. Agric. Engng. Res. 59:7387. 
Hayes, M. D., H. Xin, H. Li, T. A. Shepherd, Y. Zhao, and J. P. Stinn. 2013. Heat and Moisture Production of Hy-Line Brown Hens in Aviary Houses in the Midwestern U.S. 56(2).

Heber, A.J., Bogan, B.W., Ramirez-Dorronsoro, J.-C.D., Ni, J.-Q., Lim, T.T., Cortus, E.L., Diehl, C.A., Hanni, S.M., 2007. Quality Assurance Project Plan for the National Air Emissions Monitoring Study (Barns Component); Revision 2.0. Purdue University, West Lafayette, IN.

HFAC Laying Hen Standards (2014). Egg laying hens. http://certifiedhumane.org/wpcontent/uploads/2014/03/Std14.Layers.2A1.pdf . Accessed on August 31, 2016.

Li, Q.-F., L. Wang-Li, K. Wang, L. Chai, E. L. Cortus, I. Kilic, B. W. Bogan, N. Ji-Qin, and A. J. Heber. 2013. The National Air Emissions Monitoring Study's Southeast Layer Site: Part II. Particulate Matter. Transactions of the ASABE 56(3).

Liang, W., A. Heber, J. Ni, E. Cortus, B. Bogan, K. Wang, L. Wang-Li, Q. Li, R. Zhang, and X. Lin. 2013. HIGH RISE LAYER HOUSE AMMONIA EMISSIONS MEASURED BY THE NAEMS. Emissions of Ga sand Dust from Livestock: 260.

Lin, X. J., E. L. Cortus, R. Zhang, S. Jiang, and A. J. Heber. 2012. Ammonia, Hydrogen Sulfide, Carbon Dioxide and Particulate Matter Emissions from California High-Rise Layer Houses. Atmospheric Environment 46: 81-91.

Lin, X. J., R. Zhang, S. Jiang, H. M. Elmashad, and F. Mitloehner. 2015. Nutrient flow and distribution in conventional cage, enriched colony, and aviary layer houses. Poultry Science: pev307.

Lohmann Tierzucht. 2011. Lohmann brown lite management guide. Veterinary Laboratory, http://www.ltz.de.

McQuitty, J.b., J.H.R., Feddes, and J.J. Leonard (1985). Air quality in commercial laying barns. Can. Agric. Eng. 27:13-19.

Mench, J. 2013. Final Report- CAFA Agreement 09-0854 "Determination of Space Use by Laying hens". http://www.cdfa.ca.gov/ahfss/pdfs/legislation/Attach21FinalReportCDFAAgreement09_0854.pdf.

Ni, J.-Q., C. A. Diehl, L.-L. Cha, B. W. Bogan, E. L. Cortus, T. T. Lim, and A. J. Heber. 2010. National Air Emissions Monitoring Study: Emissions Data from Two Manure Belt Layer Houses in Indiana - Site IN2B. Final Report. Purdue University, West Lafayette, IN, July 2.

Ni, J.-Q., L. Chai, L. Chen, B. W. Bogan, K. Wang, E. L. Cortus, A. J. Heber, T.-T. Lim, and C. A. Diehl. 2012. Characteristics of ammonia, hydrogen sulfide, carbon dioxide, and particulate matter concentrations in high-rise and manure-belt layer hen houses. Atmospheric Environment 57: 165174.USDA. 2013. Chickens and Eggs. ISSN 1948 - 9064.

Pedersen, S. and C.B. Pedersen. 1995. Animal activity measured by infrared detectors. Journal of Agricultural Engineering Research 61(4): 239-246. 
Shepherd, T. A., Y. Zhao, H. Li, J. P. Stinn, M. D. Hayes, and H. Xin. 2015. Environmental assessment of three egg production systems-Part II. Ammonia, greenhouse gas, and particulate matter emissions. Poultry Science 94(3): 534-543.

USDA. 2014. Chickens and Eggs. ISSN: 1948-9064.

Wang-Li, L., Q.-F. Li, L. Chai, E. L. Cortus, K. Wang, I. Kilic, B. W. Bogan, J.-Q. Ni, and A. J. Heber. 2013. The National Air Emissions Monitoring Study's Southeast Layer Site: Part III. Ammonia Concentrations and Emissions. Transactions of the ASABE 56(3).

Xin, H., Gates, R.S., Green, A.R., Mitloehner, F.M., Moore, P.A., Wathes, C.M., 2011. Environmental impacts and sustainability of egg production systems. Poultry Science 90:261-277.

Zhao, Y., T. A. Shepherd, J. Swanson, J. Mench, D. Karcher, and H. Xin. 2015a. Comparative evaluation of three egg production systems: Housing characteristics and management practices. Poultry Science 94(3): 475-484.

Zhao, Y., T. A. Shepherd, H. Li, and H. Xin. 2015b. Environmental assessment of three egg production systems-Part I: Monitoring system and indoor air quality. Poultry science 94(3): 518-533.

Zhao, Y., H. Xin, T. A. Shepherd, M. D. Hayes, J. P. Stinn, and H. Li. 2013. Thermal environment, ammonia concentrations and emission emissions of aviary houses with white laying hens. Transactions of the ASABE 56(3): 1145-1156. 